\title{
Phase Evolution in Silicon Carbide-Whisker-Reinforced Mullite/Zirconia Composite during Long-Term Oxidation at $1000^{\circ}$ to $1350^{\circ} \mathrm{C}$
}

\author{
Chien-Cheng Lin ${ }^{*} \dagger$ \\ Department of Materials Science and Engineering, National Chiao Tung University, Hsinchu 300, Taiwan \\ Avigdor Zangvil ${ }^{\star}$ \\ Frederick Seitz Materials Research Laboratory and Department of Materials Science and Engineering,
} University of Illinois, Urbana, Illinois 61801

Robert Ruh ${ }^{\star, *}$

Air Force Research Laboratory, Wright-Patterson AFB, Ohio 45433

A composite consisting of $30 \mathrm{wt} \% \mathrm{SiC}$ whiskers and a mullitebased matrix (mullite-32.4 wt\% $\mathrm{ZrO}_{2}-2.2 \mathrm{wt} \% \mathrm{MgO}$ ) was isothermally exposed in air at $1000^{\circ}-1350^{\circ} \mathrm{C}$, for up to $1000 \mathrm{~h}$. Microstructural evolution in the oxidized samples was investigated using $\mathrm{X}$-ray diffractometry and analytical transmission electron microscopy. Amorphous $\mathrm{SiO}_{2}$, formed through the oxidation of $\mathrm{SiC}$ whiskers, was devitrified into cristobalite at $T \geq 1200^{\circ} \mathrm{C}$ and into quartz at $1000^{\circ} \mathrm{C}$. At $T \geq 1200^{\circ} \mathrm{C}$, the reaction between $\mathrm{ZrO}_{2}$ and $\mathrm{SiO}_{2}$ resulted in zircon, and prismatic secondary mullite grains were formed via a solutionreprecipitation mechanism in severely oxidized regions. Ternary compounds, such as sapphirine and cordierite, also were found after long-term exposure at $T \geq 1200^{\circ} \mathrm{C}$.

\section{Introduction}

C ERAMIC-MATRIX composites toughened by $\mathrm{SiC}$ whiskers are possible candidates for use in high-temperature environments. ${ }^{1-7}$ Thus, the oxidation behavior of these composites at high temperatures is of great concern. ${ }^{8-17}$ Previous studies ${ }^{6-9,14,15}$ have indicated that the oxidation behavior and mechanical properties of SiC-whisker or particulate-reinforced ceramic-matrix composites are strongly affected by the reaction between the oxidation product (i.e., $\mathrm{SiO}_{2}$ ) and the matrix.

Porter and $\mathrm{Chokshi}^{6}$ and Becher and Tiegs ${ }^{7}$ suggested that the mechanical properties of $\mathrm{SiC}$-whisker-reinforced $\mathrm{Al}_{2} \mathrm{O}_{3}$ are related to the oxidation of $\mathrm{SiC}$ whiskers and to the subsequent reaction of $\mathrm{SiO}_{2}$ with the $\mathrm{Al}_{2} \mathrm{O}_{3}$ matrix. Some studies ${ }^{8-10}$ revealed that the parabolic rate constants of $\mathrm{SiC}$ in an $\mathrm{Al}_{2} \mathrm{O}_{3}$ or mullite matrix were much higher than those expected for the oxidation of bulk $\mathrm{SiC}$, because a liquid aluminosilicate phase was formed following the reaction between the oxidation product and the matrix. Tsai and co-workers ${ }^{15,16}$ reported that various oxidation modes were operative in mullite/ $\mathrm{ZrO}_{2} / \mathrm{SiC}$ composites, depending on the $\mathrm{ZrO}_{2}$ content. Those researchers also found that the oxidation mode

D. P. Butt-contributing editor

Manuscript No. 189432. Received April 8, 1999; approved November 1, 1999.

Supported by the National Science Council, Taiwan, under Contract No. NSC872216-E-009-014

${ }^{*}$ Member, American Ceramic Society.

Author to whom correspondence should be addressed.

Presently at Universal Technology Corporation, Beavercreek, OH 45432. could be affected, because of the zircon formation, by the reaction between $\mathrm{SiO}_{2}$ and $\mathrm{ZrO}_{2}$. However, very little detailed description of the resultant microstructures and the oxide-formation mechanisms has been provided to date, even though such description is crucial to a full understanding of the oxidation behavior of composites with $\mathrm{SiC}$ reinforcements.

Recently, Lin et al. ${ }^{17}$ described the microscopic mechanisms of the oxidation of $\mathrm{SiC}$ whiskers in mullite-matrix and $\mathrm{ZrO}_{2}-$ containing mullite-matrix composites, mainly based on transmission electron microscopy (TEM) observations of individual oxidized $\mathrm{SiC}$ whiskers at various depths. Those studies focused on the early stages of oxidation, in locations where unoxidized SiC was still available.

The purpose of the present study is to explore the microstructural variations caused by the interdiffusion and chemical reactions between the oxide product and the matrix during the long-term oxidation of $\mathrm{SiC}$-whisker-reinforced mullite $/ \mathrm{ZrO}_{2}$ composites. The microstructures of the oxidized samples of various composites after exposure in the temperature range $1000^{\circ}-1350^{\circ} \mathrm{C}$, for up to $1000 \mathrm{~h}$ in air, were studied using X-ray diffractometry (XRD), TEM, and energy-dispersive spectroscopy (EDS).

\section{Experimental Procedure}

The matrix of the composite was prepared by the sol-gel process, starting with the alkoxides of silicon, aluminum, zirconium, and magnesium. The matrix consisted of mullite- $32.4 \mathrm{wt} \%$ $\mathrm{ZrO}_{2}-2.2 \mathrm{wt} \% \mathrm{MgO}$. After $30 \mathrm{wt} \% \mathrm{SiC}$ whiskers (Silar SC-9, Arco Chemical Co., now Advanced Composite Materials Corp., Greer, SC), had been incorporated into the alkoxides, the mixtures were hot-pressed (Model No. 1-2300, Centorr Furnaces/Vacuum Industries, Inc., Nashua, NH) in graphite dies lined with graphite foil at $1400^{\circ} \mathrm{C}$, under $34.5 \mathrm{MPa}$, for $20 \mathrm{~min}$ in an argon atmosphere. The crystalline phases (determined by XRD) of the hot-pressed samples included mullite, tetragonal and monoclinic $\mathrm{ZrO}_{2}, \mathrm{SiC}$, and traces of spinel and zircon, as described by a previous study. ${ }^{18}$

Composite samples measuring $\sim 10 \mathrm{~mm} \times 6 \mathrm{~mm} \times 3 \mathrm{~mm}$ were exposed isothermally in air, at temperatures ranging from $1000^{\circ}$ to $1350^{\circ} \mathrm{C}$, for up to $1000 \mathrm{~h}$. Before exposure, all of the surfaces were ground on $\mathrm{SiC}$ sandpaper from 240 grit to 600 grit, in sequence, and polished with $3 \mu \mathrm{m}$ diamond paste on nylon cloth. Samples were inserted into a box furnace (Model No. 51333, Lindberg Corp., St. Louis, MO) preheated to the desired temperature. The exposed samples, as well as the hot-pressed samples, were characterized by XRD, as described elsewhere. ${ }^{17}$ Both cross-sectional 
and plain-viewed samples were investigated, using analytical TEM (Model No. EM 420, Philips Research Laboratories, Eindhoven, The Netherlands), as described elsewhere. ${ }^{17}$ The Cliff-Lorimer standardless ratio technique ${ }^{19}$ was used to estimate the compositions of the various oxidation products. The technique was performed on the TEM, equipped with an ultrathin window EDS detector (Model No. 9900, EDAX International, Prairie View, IL). For the measurement of the unknown compositions, all of the compounds were presumed to be composed of various stoichiometric oxides, such as $\mathrm{MgO}, \mathrm{Al}_{2} \mathrm{O}_{3}, \mathrm{SiO}_{2}$, and $\mathrm{ZrO}_{2}$.

\section{Results and Discussion}

\section{(1) XRD Analyses}

Table I shows the relative XRD intensities of various phases in the hot-pressed and exposed samples. The reaction of the oxidation product(s) and the matrix was insignificant at $1000^{\circ} \mathrm{C}$, even though $\mathrm{SiC}$ whiskers were completely oxidized at the outer surface. At temperatures of $>1200^{\circ} \mathrm{C}$, the reaction of the oxide layer of $\mathrm{SiC}$ whiskers with the matrix produced new phases. The formation of ternary sapphirine and/or cordierite phases was caused by the reactions among $\mathrm{MgO}, \mathrm{Al}_{2} \mathrm{O}_{3}$, and $\mathrm{SiO}_{2}$, while the reactions between $\mathrm{ZrO}_{2}$ and $\mathrm{SiO}_{2}$ and between $\mathrm{MgO}$ and $\mathrm{Al}_{2} \mathrm{O}_{3}$ resulted in zircon and aluminum-magnesium spinel, respectively. The amorphous background intensity at $20^{\circ} \leq 2 \theta \leq 30^{\circ}$ in the XRD spectra at $1350^{\circ} \mathrm{C}$ for 260 or $1000 \mathrm{~h}$ was caused mainly by the amorphous aluminosilicate phase, formed through the reaction of $\mathrm{SiO}_{2}, \mathrm{Al}_{2} \mathrm{O}_{3}$, and other impurities, while the background in the same angles from the sample after exposure at $1000^{\circ}$ or $1350^{\circ} \mathrm{C}$ for $1 \mathrm{~h}$ was caused by the amorphous $\mathrm{SiO}_{2}$ oxidation product.

\section{(2) TEM Observation}

(A) Devitrification of Silica: When SiC-whisker-reinforced mullite-matrix composites were exposed to high-temperature oxidizing environments, $\mathrm{SiC}$ whiskers in the outer region were oxidized via an oxygen-inward diffusion mechanism. The oxidation of $\mathrm{SiC}$ whiskers is expressed by the following reaction:

$$
\mathrm{SiC}+\frac{3}{2} \mathrm{O}_{2} \rightarrow \mathrm{SiO}_{2}(\text { silica })+\mathrm{CO}
$$

The oxidation product of $\mathrm{SiC}$ whiskers was amorphous $\mathrm{SiO}_{2}$. However, after long periods, the amorphous $\mathrm{SiO}_{2}$ devitrified into various polymorphic forms of crystalline $\mathrm{SiO}_{2}$, depending on the exposure conditions. Figure 1(a) shows several low-quartz grains, marked "Q," in the composite after exposure at $1000^{\circ} \mathrm{C}$ for $1000 \mathrm{~h}$. Presumably, those grains experienced the high $\rightarrow$ low displacive transformation at $\sim 573^{\circ} \mathrm{C}$ when they were cooled to room temperature. ${ }^{20}$ Inset at the upper right corner of Fig. 1(a) is the selected area diffraction pattern (SADP) of quartz. The EDS analysis (not shown) revealed that these quartz grains usually contain a small amount of $\mathrm{Al}_{2} \mathrm{O}_{3}$ in solid solution. At temperatures $\geq 1200^{\circ} \mathrm{C}$, cristobalite formed within the $\mathrm{SiO}_{2}$ layer. Figure 1(b) shows the micrograph of low or $\alpha$-cristobalite, with its SADP inset at the upper right corner. Cristobalite was very unstable under the electron beam, presumably because of beam heating. Twins in
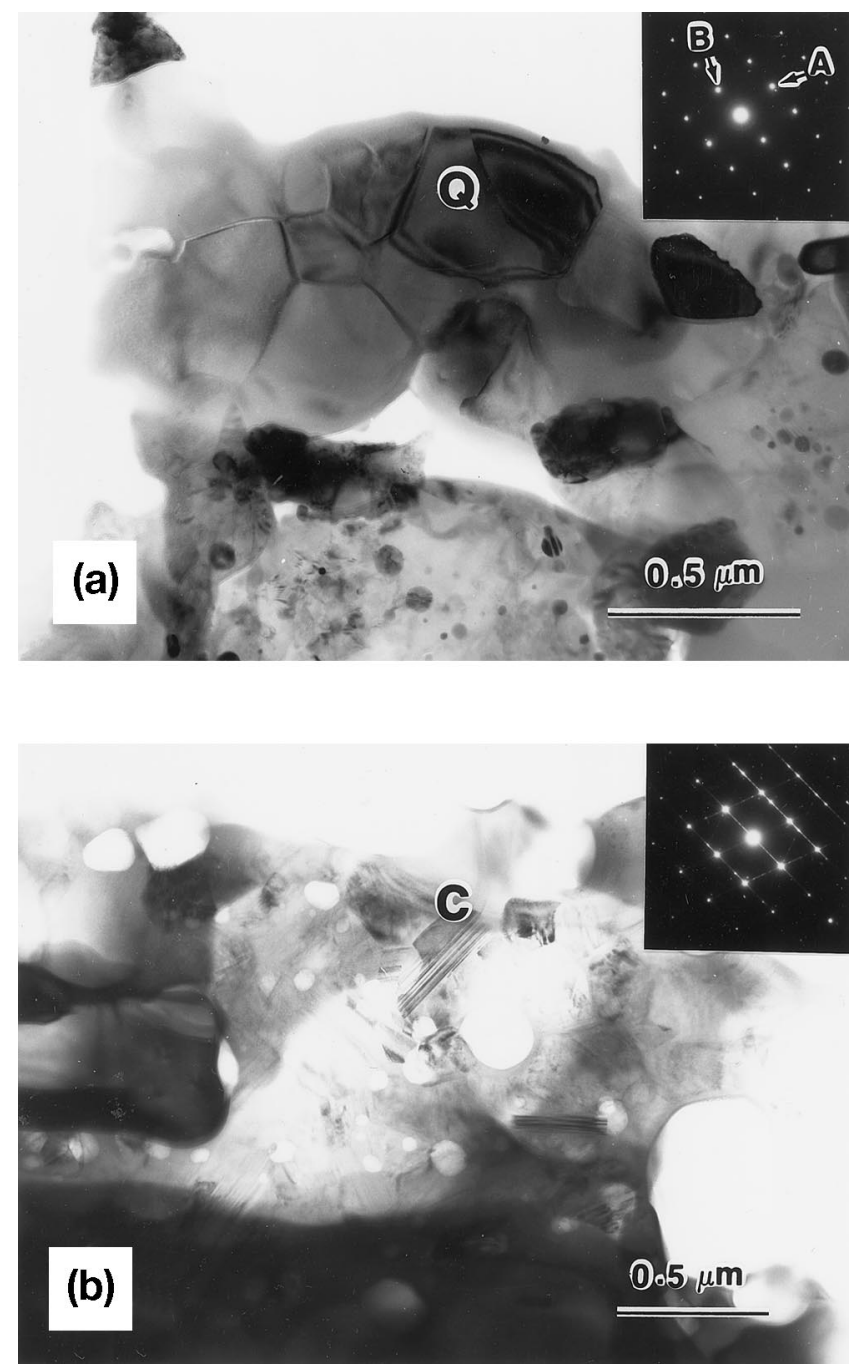

Fig. 1. (a) Quartz, marked "Q," in the sample after exposure at $1000^{\circ} \mathrm{C}$ for $1000 \mathrm{~h}(\mathrm{~A}=(\overline{1} 2 \overline{1} 0)$ and $\mathrm{B}=(0001)$ in the inset SADP $)$ and $(\mathrm{b})$ twinned $\alpha$-cristobalite, marked " $\mathrm{C}$," in the sample after exposure at $1200^{\circ} \mathrm{C}$ for $500 \mathrm{~h}$.

$\alpha$-cristobalite were caused by the $\beta \rightarrow \alpha$ displacive transformation at $\sim 200^{\circ}-275^{\circ} \mathrm{C}^{21-23}$

(B) Formation of Aluminum-Magnesium Spinel: As mentioned elsewhere, ${ }^{18} \mathrm{MgAl}_{2} \mathrm{O}_{4}$ spinel with stoichiometric composition uniformly existed in the matrix of the hot-pressed samples as separate $(\sim 0.2 \mu \mathrm{m})$ grains. Figure 2 shows that a significantly larger amount of $\mathrm{MgAl}_{2} \mathrm{O}_{4}$ spinel in the outer oxide layer of the sample formed after exposure at $1200^{\circ} \mathrm{C}$ for $500 \mathrm{~h}$. The formation of spinel required a sufficient amount of $\mathrm{MgO}$, probably supplied by exsolution from the mullite matrix and/or long-range diffusion

Table I. X-ray Diffraction Intensities for Various Phases in As-Hot-Pressed and Exposed Samples

\begin{tabular}{|c|c|c|c|c|c|c|c|c|c|c|c|}
\hline \multirow[b]{2}{*}{ Conditions } & \multicolumn{11}{|c|}{ Phase and intensity ${ }^{\dagger}$} \\
\hline & Mullite & $t-\mathrm{ZrO}_{2}$ & $m-\mathrm{ZrO}_{2}$ & $\mathrm{SiC}^{+}$ & Spinel & Cristobalite & Quartz & Sapphirine & Cordierite & Zircon & Amorphous ${ }^{\S}$ \\
\hline As hot-pressed & vs & VS & $\mathrm{m}$ & VS & vW & & & & & & \\
\hline $1000^{\circ} \mathrm{C} / 260 \mathrm{~h}$ & $\mathrm{~S}$ & Vs & $\mathrm{m}$ & vs & vw & & & & & & W \\
\hline $1000^{\circ} \mathrm{C} / 1000 \mathrm{~h}$ & $\mathrm{~S}$ & vs & vs & vs & vw & & W & & & & W \\
\hline $1200^{\circ} \mathrm{C} / 500 \mathrm{~h}$ & $\mathrm{~S}$ & vs & $\mathrm{m}$ & $\mathrm{S}$ & vw & vS & & $\mathrm{S}$ & $\mathrm{t}$ & & \\
\hline $1350^{\circ} \mathrm{C} / 1 \mathrm{~h}$ & $\mathrm{~S}$ & vs & W & vs & w & vW & & $\mathrm{t}$ & & & W \\
\hline $1350^{\circ} \mathrm{C} / 20 \mathrm{~h}$ & $\mathrm{~m}$ & vs & W & vs & $\mathrm{m}$ & $\mathrm{m}$ & & $\mathrm{m}$ & vS & $\mathrm{S}$ & \\
\hline $1350^{\circ} \mathrm{C} / 260 \mathrm{~h}$ & W & $\mathrm{W}$ & W & $\mathrm{W}$ & W & vW & & & vs & VS & $\mathrm{S}$ \\
\hline $1350^{\circ} \mathrm{C} / 1000 \mathrm{~h}$ & VW & vW & vW & vW & & vW & & $\mathrm{W}$ & vs & vS & S \\
\hline
\end{tabular}

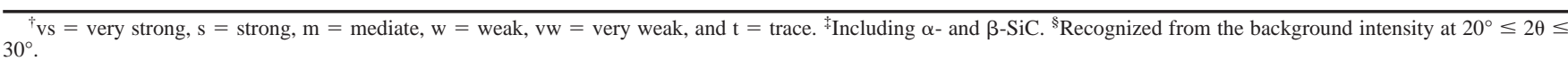




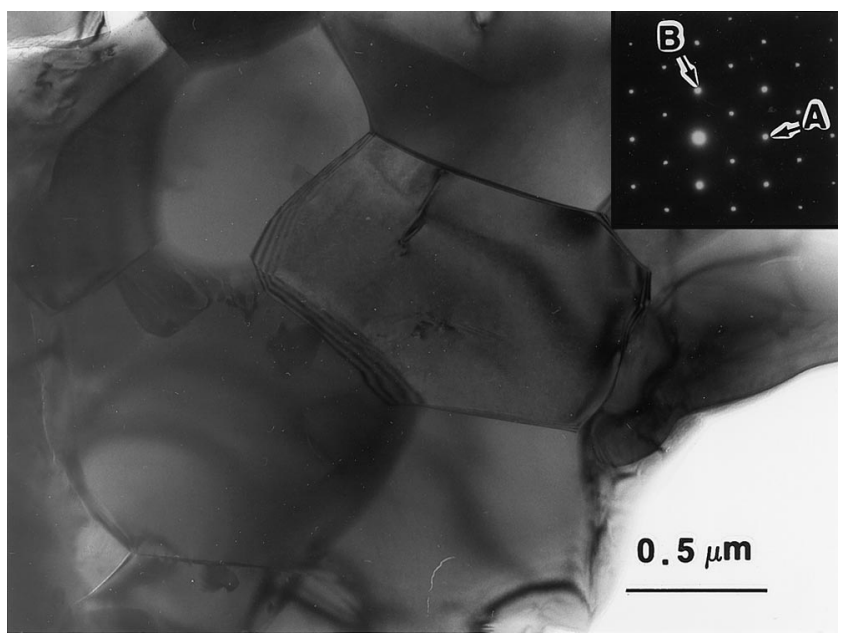

Fig. 2. Several spinel grains in the outer oxide layer of the sample after exposure at $1200^{\circ} \mathrm{C}$ for $500 \mathrm{~h}$; inset SADP was in the [011] zone $(\mathrm{A}=$ $(02 \overline{2})$ and $\mathrm{B}=(200))$

across the sample. In the stoichiometric spinel, only one-eighth of the tetragonal interstitial sites and one-half of the octahedral interstitial sites were occupied. Therefore, a solid solution of various elements in spinel was expected. The solid solution of $\mathrm{MgO}$ in $\mathrm{MgAl}_{2} \mathrm{O}_{4}$ spinel was negligible, but an appreciable amount of $\mathrm{Al}_{2} \mathrm{O}_{3}$ was soluble. According to previous studies, ${ }^{24-26}$ the composition of the spinel had a wide range, from $\mathrm{MgO} \cdot \mathrm{Al}_{2} \mathrm{O}_{3}$ to $\mathrm{Al}_{2} \mathrm{O}_{3}$. Thus, the chemical formula of that spinel can be expressed as $\mathrm{MgO} \cdot n \mathrm{Al}_{2} \mathrm{O}_{3}$. The formation of $\mathrm{MgO} \cdot n \mathrm{Al}_{2} \mathrm{O}_{3}$ spinel after exposure at $T \geq 1200^{\circ} \mathrm{C}$ resulted from the reaction

$$
\mathrm{MgO}+n \mathrm{Al}_{2} \mathrm{O}_{3} \rightarrow \mathrm{MgO} \cdot n \mathrm{Al}_{2} \mathrm{O}_{3} \text { (spinel) }
$$

The aluminum-magnesium spinel had a very representative composition of (in wt\%) $23.2 \mathrm{MgO}, 69.9 \mathrm{Al}_{2} \mathrm{O}_{3}$, and $6.9 \mathrm{SiO}_{2}$. This composition corresponded to $\mathrm{MgO} \cdot 1.18 \mathrm{Al}_{2} \mathrm{O}_{3}$, with some $\mathrm{SiO}_{2}$ in solid solution. In contrast, no silicon was detected in the spinel by EDS analysis of the hot-pressed sample, as mentioned elsewhere. $^{18}$

(C) Formation of Sapphirine: Because the XRD spectrum of sapphirine is very similar to that of $\mathrm{MgAl}_{2} \mathrm{O}_{4}$ spinel, it is difficult to distinguish between the two spectra by the XRD analysis only. However, sapphirine was easily recognized under TEM, as well as EDS, because of its special features. In the present study, sapphirine was found in the samples after exposure at $1200^{\circ} \mathrm{C}$ for $500 \mathrm{~h}$ and at $1350^{\circ} \mathrm{C}$ for $1 \mathrm{~h}$. The formation of sapphirine is related to the spinel by the following reaction:

$$
\begin{aligned}
2 \mathrm{MgAl}_{2} \mathrm{O}_{4}(\text { spinel })+ & \mathrm{SiO}_{2}(\text { silica }) \rightarrow \\
& 2 \mathrm{MgO} \cdot 2 \mathrm{Al}_{2} \mathrm{O}_{3} \cdot \mathrm{SiO}_{2}(\text { sapphirine })
\end{aligned}
$$

The 2:2:1 ratio is only approximate. The actual composition of sapphirine has a very wide range, which can be expressed by a general formula: $\mathrm{Mg}_{7} \mathrm{Al}_{22-x} \mathrm{Si}_{0.75 x} \mathrm{O}_{40}$, with $1.5 \leq x \leq 5.6 .{ }^{27,28} \mathrm{In}$ the present study, the composition of sapphirine was estimated using the Cliff-Lorimer method. The measured $x$ value range was $2.8-4.8$.

The most common polytypes in sapphirine are sapphirine-1Tc and sapphirine-2M. The former has a one-layered structure along $\boldsymbol{b}^{*}$, with $b \approx 0.72 \mathrm{~nm}$; the latter has a two-layered structure, with $b \approx 1.44 \mathrm{~nm} .{ }^{29}$ Figure 3(a) shows the image of the sapphirine in the composite after exposure at $1200^{\circ} \mathrm{C}$ for $500 \mathrm{~h}$. The sapphirine had a characteristic needlelike shape, with the needle axis parallel to $\boldsymbol{a}^{*}$. Twin boundaries also were revealed. For convenience, the SADP of the sapphirine (inset in the upper right corner) was indexed as having a monoclinic unit cell. However, the unit cell was identified as triclinic twinned sapphirine-1Tc, with a (010) twin plane. The superlattice spots of $l=2 n+1$ were weaker than the basic spots of $l=2 n$. However, they displayed the true
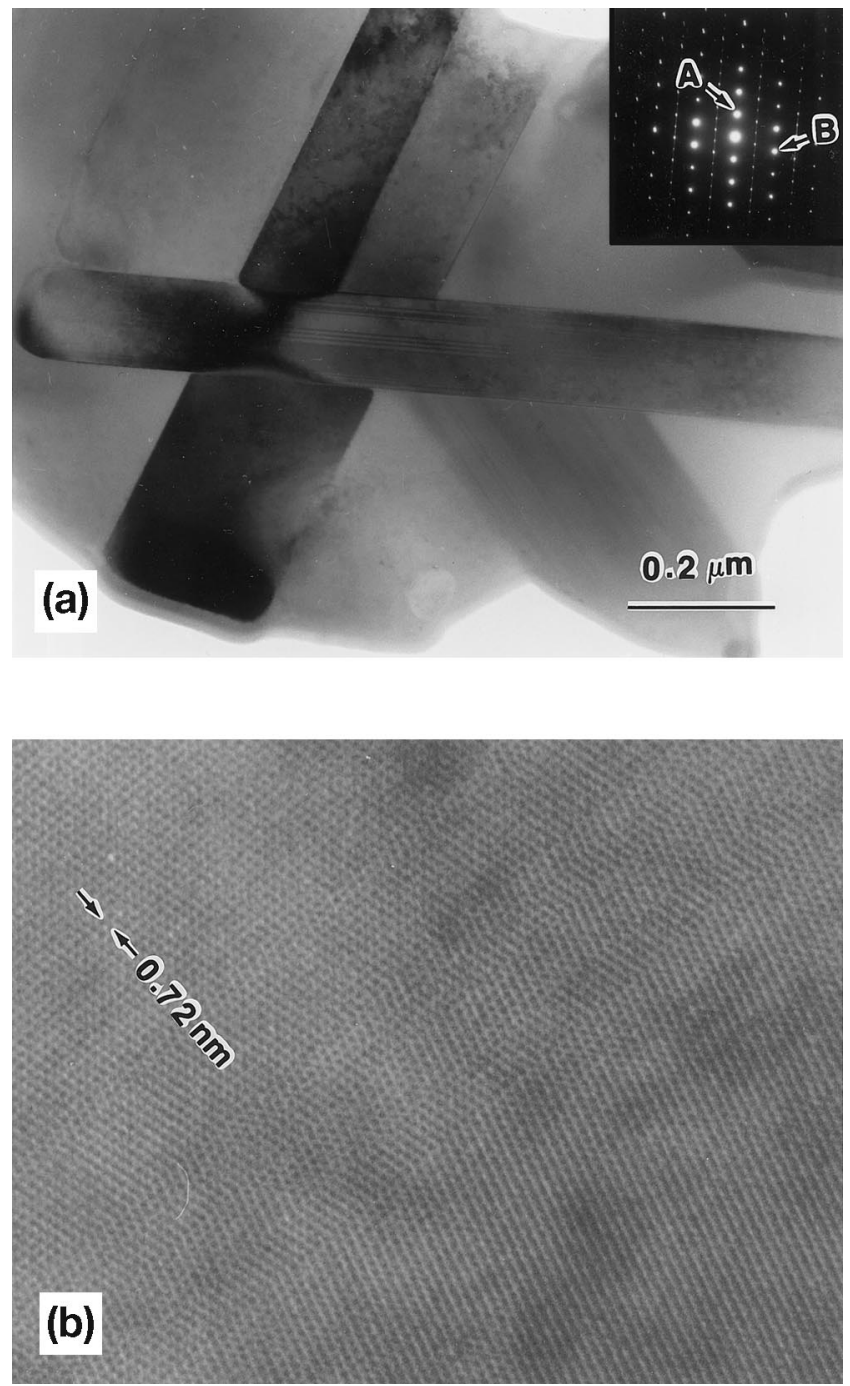

Fig. 3. (a) Needlelike sapphirine in the sample after exposure at $1200^{\circ} \mathrm{C}$ for $500 \mathrm{~h}$; SADP was indexed as the monoclinic symmetry, for convenience, indicating the $1 \mathrm{Tc}$ structure in the $[100]_{\mathrm{M}}$ zone $\left(\mathrm{A}=(020)_{\mathrm{M}}\right.$ and $\left.\mathrm{B}=(0 \overline{1} 2)_{\mathrm{M}}\right)$. (b) High-resolution micrograph, showing the sapphirine-1Tc structure, with $(010)_{M}$ twin planes.

periodicity of the unit cell along $\boldsymbol{b}^{*}$ and the streaking caused by the stacking disorder. ${ }^{29}$ In the present study, high-resolution TEM techniques were attempted to explore the stacking sequence on an atomic scale, and the result indicated that the sapphirine found was basically the twinned 1Tc form (Fig. 3(b)).

Barbier and $\mathrm{Hyde}^{30}$ described sapphirine as a regular intergrowth at the unit-cell level of the slabs of the spinel and clinopyroxene structures. The ideal stoichiometric sapphirine can be written as follows:

$$
\begin{aligned}
& \left.\mathrm{Mg}_{4} \mathrm{Al}_{8} \mathrm{Si}_{2} \mathrm{O}_{20} \text { ( sapphirine }\right) \rightarrow \\
& \quad 2 \mathrm{MgAl}_{2} \mathrm{O}_{4}(\text { spinel })+2 \mathrm{MgAl}_{2} \mathrm{SiO}_{6}(\text { clinopyroxene })
\end{aligned}
$$

However, in the present cases, spinel was embedded in sapphirine, as shown in Figs. 4(a) and (c). Figure 4(a) is the bright-field image, and Fig. 4(c) displays the dark-field image obtained by the $(\overline{2} 20)$ diffracted spot of spinel. This image implies that spinel may be the precursor of sapphirine, as mentioned above. The SADP in Fig. 4(b) indicates that the orientation relationships between spinel and sapphirine are $\langle 110\rangle_{\mathrm{sp}} \|\langle 100\rangle_{\mathrm{sapph}}$ and $\{\overline{1} 10\}_{\mathrm{sp}} \|\{010\}_{\mathrm{sapph}}$.

In the present study, we also found that sapphirine structures were unstable under strong heating of the electron beam. The clinopyroxene became amorphous under the intensive electronbeam heating, and the spinel was simultaneously transformed into micrograins. 

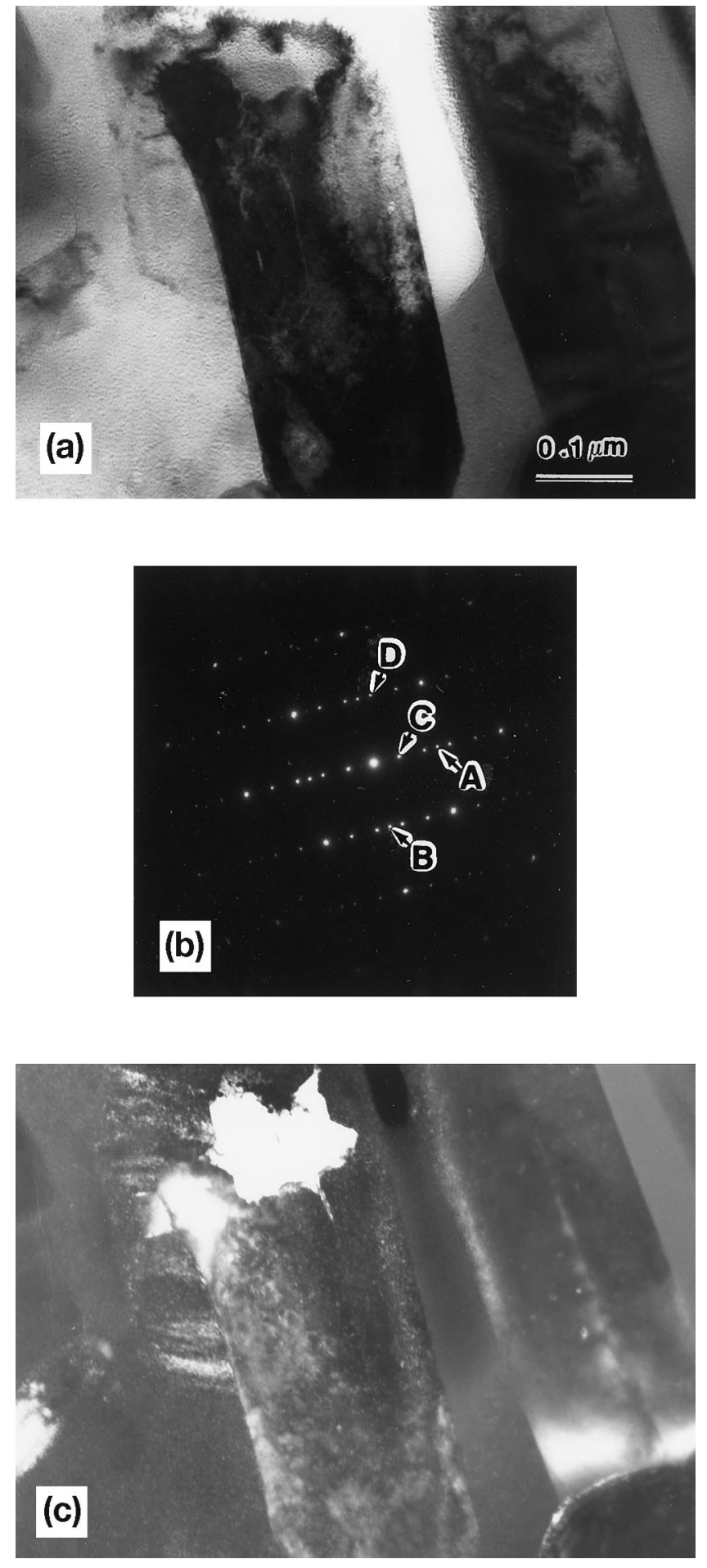

Fig. 4. (a) Spinel grain embedded in sapphirine; (b) SADP from the area, including spinel and sapphirine, indicating that $[110]_{\mathrm{sp}} \|[100]_{\mathrm{sapph}}$ and $(\overline{1} 10)_{\mathrm{sp}} \|(010)_{\mathrm{sapph}}\left(\mathrm{A}=(\overline{2} 20)_{\mathrm{sp}}, \mathrm{B}=(220)_{\mathrm{sp}}, \mathrm{C}=(020)_{\mathrm{sapph}}, \mathrm{D}=\right.$ $\left.(\overline{4} 12)_{\text {sapph }}\right)$; (c) dark-field image obtained by the $(\overline{2} 20)_{\text {sp }}$ diffraction spot.

(D) Formation of Cordierite: There are two common polymorphic forms of cordierite: $:^{31,32}$ high cordierite, with a hexagonal crystal structure, and low cordierite, with an orthorhombic crystal structure. The hexagonal-to-orthorhombic transformation involves the Al,Si ordering, which is characterized by the splitting of the (211) peak of the hexagonal cordierite into (151), (241), and (311) of the orthorhombic cordierite in the XRD spectrum. Distortion indexes, $\Delta$, were defined by Miyashiro ${ }^{33}$ and measured by Putnis and co-workers, ${ }^{34,35}$ who found $\Delta=0$ in the hexagonal cordierite and $\Delta \approx 0.25$ in the orthorhombic cordierite, with intermediate values for the continuous $\mathrm{Al}$,Si ordering sequence from high to low cordierite. Measured distortion indexes indicate that the cordierite exposed at $1200^{\circ} \mathrm{C}$ for $500 \mathrm{~h}$ or at $1350^{\circ} \mathrm{C}$ for $260 \mathrm{~h}$ was hexagonal (corresponding to $\Delta=0.07$ or $\Delta=0.00$ ), whereas that exposed at $1350^{\circ} \mathrm{C}$ for $1000 \mathrm{~h}$ was orthorhombic $(\Delta=0.19)$.

Figure 5 shows the microstructures of the cordierite formed under different exposure conditions. Figure 5(a) displays the hexagonal cordierite (marked "C"), along with several needlelike sapphirine grains in the sample, after exposure at $1200^{\circ} \mathrm{C}$ for $500 \mathrm{~h}$. A defect-free and homogeneous microstructure was observed. The cordierite formed at $1350^{\circ} \mathrm{C}$ for $260 \mathrm{~h}$ is shown in Fig. 5(b). This cordierite had a characteristic tweedlike microstructure. The "threads" lay on the $\{1 \overline{1} 10\}$ or $\{\overline{2} 110\}$ planes, as indicated by the streaking in the SADP. Figure 5(c) shows that the cordierite in the composite after exposure at $1350^{\circ} \mathrm{C}$ for $1000 \mathrm{~h}$ usually contained defects, such as dislocations, elongated loops, dipoles, and $\pi$-type boundaries, as described by van Roermund and Konert. ${ }^{36}$ Subgrains in cordierite also were observed in the present study. The SADP in Fig. 5(d) shows the split diffraction spots caused by the low-angle $\left(\sim 2^{\circ}\right)$ boundary. Spherical $\mathrm{ZrO}_{2}$ particles frequently were observed embedded in cordierite. The $\mathrm{ZrO}_{2}$ acted as a nucleating agent of cordierite, as is the case in the cordierite$\mathrm{ZrO}_{2}$ glass-ceramic system. ${ }^{37-39}$

The sequence for the phase transformation of cordierite during oxidation at $T \geq 1200^{\circ} \mathrm{C}$ can be described as follows: hexagonal cordierite $\rightarrow$ modulated hexagonal cordierite $\rightarrow$ orthorhombic cordierite. This sequence is consistent with the result reported by Putnis. ${ }^{34}$ At temperatures between $1050^{\circ}$ and $1445^{\circ} \mathrm{C}$, the first crystallization product of the stoichiometric magnesium-cordierite invariably was hexagonal cordierite, which eventually transformed, on annealing, to orthorhombic cordierite via an intermediate modulated structure.

Cordierite grains had a rodlike appearance, presumably "inherited" from that of sapphirine, as shown in Fig. 5(c). The axes of the rodlike cordierite crystals in Fig. 5(c) are parallel to $c^{*}$. This orientation implies that cordierite was formed from sapphirine, simply by the incorporation of additional $\mathrm{SiO}_{2}$, supplied by the further oxidation of $\mathrm{SiC}$ whiskers. Thus, the formation of cordierite can be illustrated by the following reaction:

$$
\begin{aligned}
2 \mathrm{MgO} \cdot 2 \mathrm{Al}_{2} \mathrm{O}_{3} \cdot \mathrm{SiO}_{2} & \text { (sapphirine })+4 \mathrm{SiO}_{2}(\text { silica }) \\
& \rightarrow 2 \mathrm{MgO} \cdot 2 \mathrm{Al}_{2} \mathrm{O}_{3} \cdot 5 \mathrm{SiO}_{2}(\text { cordierite })
\end{aligned}
$$

(E) Formation of Anorthite: $\mathrm{SiC}$ whiskers contained calcium-rich inclusions in the core region. ${ }^{18} \mathrm{CaO}$ was produced by the oxidation of these calcium-rich inclusions; however, it did not exist in its free state in the exposed samples but was dissolved into the $\mathrm{SiO}_{2}$, a product of the oxidation of $\mathrm{SiC}$ whiskers. The melting point of the $\mathrm{SiO}_{2}$ was lowered by dissolving $\mathrm{CaO}$ or other impurities. This impurity-bearing liquid phase was retained as glassy phases after the samples had been cooled to room temperature. However, $\mathrm{CaO}$ and the aluminosilicates also could react to become anorthite $\left(\mathrm{CaAl}_{2} \mathrm{Si}_{2} \mathrm{O}_{8}\right)$.

Anorthite has two or three polymorphic forms: ${ }^{40}$ it experiences the series of $\mathrm{C} \overline{1} \rightarrow \mathrm{I} \overline{1} \rightarrow \mathrm{P} \overline{1}$ or $\mathrm{I} \overline{1} \rightarrow \mathrm{P} \overline{1}$ transformations when cooled from melts to room temperature. The $C \overline{1} \rightarrow I_{1}$ transformation is caused by $\mathrm{Al}, \mathrm{Si}$ ordering, whereas the $\mathrm{I} \overline{1} \rightarrow \mathrm{P} \overline{1}$ is a displacive ordering of the $\mathrm{Ca}^{2+}$ cation at $\sim 240^{\circ} \mathrm{C}$. Twinned anorthite grains, shown in Fig. 6, were found in the sample after exposure at $1200^{\circ} \mathrm{C}$ for $500 \mathrm{~h}$. From the inset SADP, the grains were identified as $\mathrm{P} \overline{1}$ anorthite, ${ }^{41,42}$ with the twin plane parallel to (010). Different domains in the anorthite phase had a similar crystallographic orientation but with angle differences of several degrees (mosaic structure). Also shown in Fig. 6 is a glassy phase (marked "G") abutting the anorthite and containing a significant amount of $\mathrm{CaO}$.

$(F)$ Formation of Zircon: Zircon formation was caused by the reaction of $\mathrm{ZrO}_{2}$ and the oxidation product, $\mathrm{SiO}_{2}$ :

$$
\mathrm{ZrO}_{2}+\mathrm{SiO}_{2} \rightarrow \mathrm{ZrSiO}_{4}(\text { zircon})
$$

Figure 7 shows a zircon grain with an imbedded residual $\mathrm{ZrO}_{2}$ particle. The morphology of zircon and $\mathrm{ZrO}_{2}$ suggests that zircon 

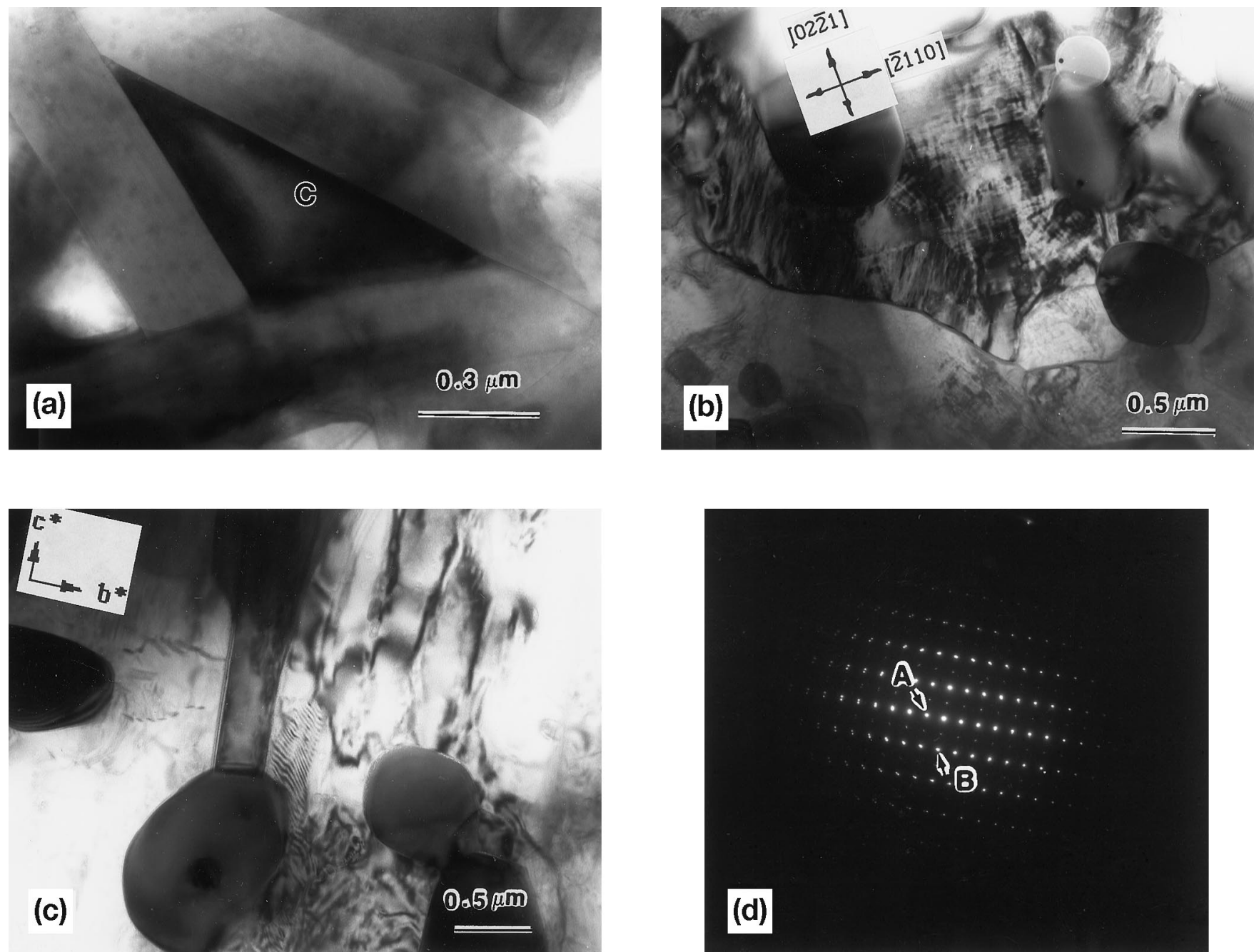

Fig. 5. (a) Hexagonal cordierite, marked " $\mathrm{C}$," in the sample after exposure at $1200^{\circ} \mathrm{C}$ for $500 \mathrm{~h}$; (b) modulated cordierite in the sample after exposure at $1350^{\circ} \mathrm{C}$ for $260 \mathrm{~h}$; (c) orthorhombic cordierite in the sample after exposure at $1350^{\circ} \mathrm{C}$ for $1000 \mathrm{~h}$; (d) SADP of the orthorhombic cordierite in (c) $(\mathrm{A}=(020)$ and $\mathrm{B}=(002))$.

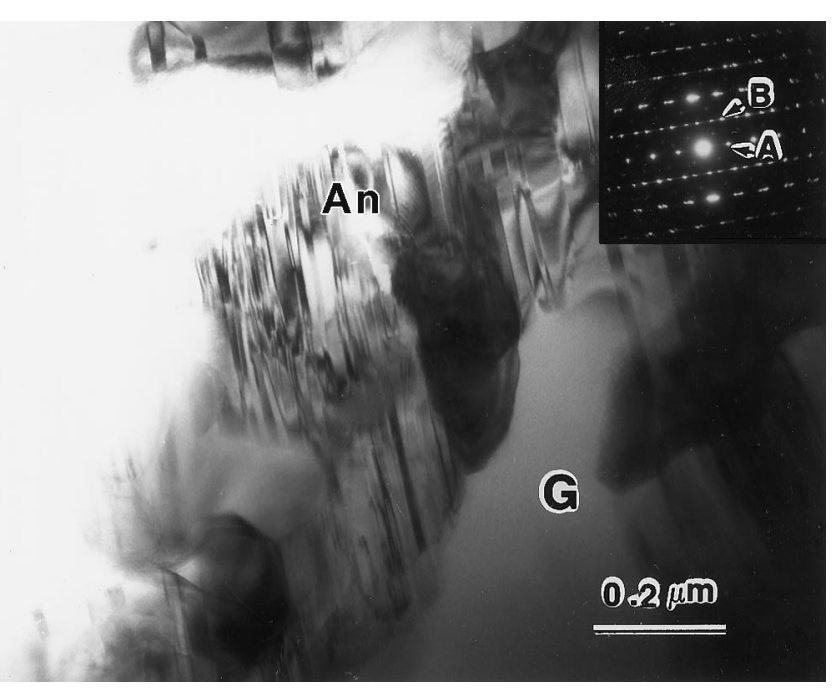

Fig. 6. Anorthite (marked "An") in the sample after exposure at $1200^{\circ} \mathrm{C}$ for $500 \mathrm{~h}$; SADP was identified as a mixture of $\mathrm{C}_{\overline{1}}$ anorthite and $\mathrm{P} \overline{1}$ anorthite, with the twin plane parallel to $(010)(\mathrm{A}=(020)$ and $\mathrm{B}=(022)$; region marked "G" is a glassy phase).

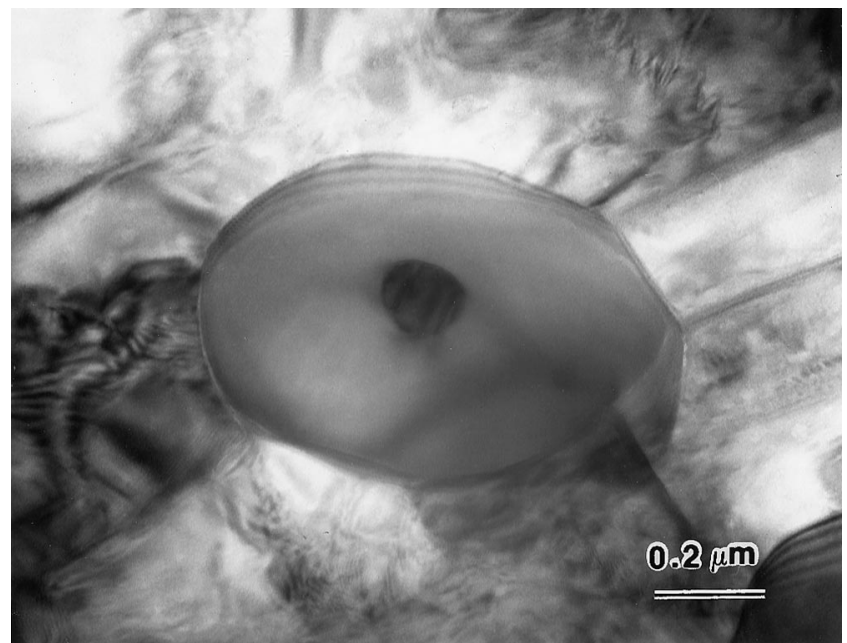

Fig. 7. Zircon grain with an embedded residual $\mathrm{ZrO}_{2}$ particle in the sample after exposure at $1350^{\circ} \mathrm{C}$ for $1000 \mathrm{~h}$. 


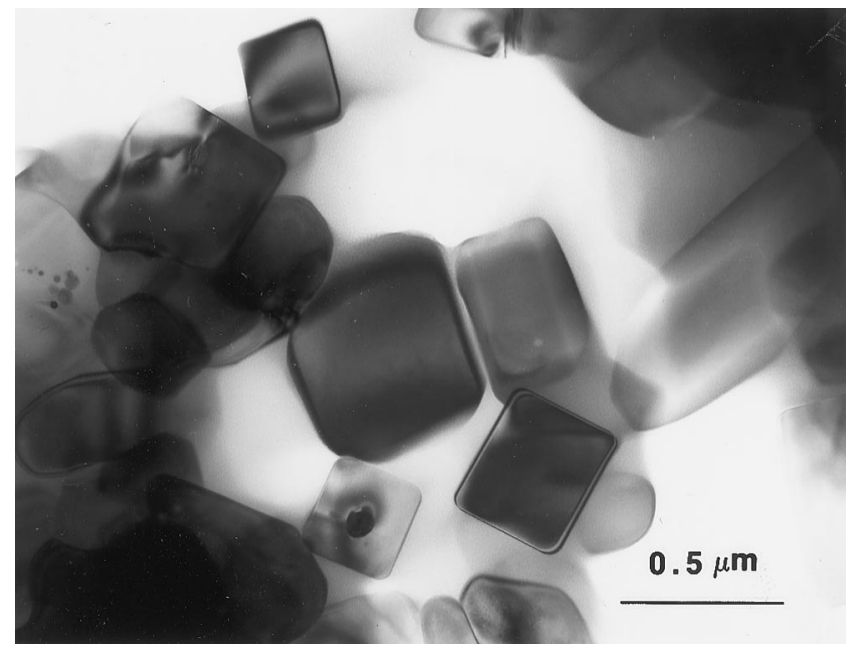

Fig. 8. Prismatic secondary mullite formed in the sample after exposure at $1350^{\circ} \mathrm{C}$ for $1000 \mathrm{~h}$.

formation is caused by inward diffusion of the $\mathrm{Si}^{4+}$. The formation mechanism of zircon is described as follows: ${ }^{43,44}$

(1) Silica diffuses to the surface of $\mathrm{ZrO}_{2}$.

(2) Zircon forms, according to the chemical reaction in Eq. (6).

(3) Silicon and oxygen diffuse inward through the zircon layer to the interface of zircon and $\mathrm{ZrO}_{2}$, where the reaction continues.

Zircon was found only in samples exposed at temperatures $\geq 1200^{\circ} \mathrm{C}$. At $T=1000^{\circ} \mathrm{C}$, the diffusion rate of $\mathrm{SiO}_{2}$ was too low for any appreciable reaction between $\mathrm{ZrO}_{2}$ and $\mathrm{SiO}_{2}$.

The residual $\mathrm{ZrO}_{2}$ particle in zircon suggests an incomplete reaction between $\mathrm{ZrO}_{2}$ and $\mathrm{SiO}_{2}$; thus, the silicon diffusion rate in zircon probably is very slow, even at $1350^{\circ} \mathrm{C}$. The low diffusion rate in zircon can be explained by the dense crystal structure of zircon, which consists of four zirconium atoms and four $\mathrm{SiO}_{4}$ tetrahedra in a unit cell. Zircon forms at the expense of zirconia, a high-diffusivity path of oxygen. This reaction explains why the oxidation rate of composites could dramatically decrease following the formation of zircon. ${ }^{15,16}$
(G) Formation of Secondary Mullite: Figure 8 shows several prismatic mullite grains and a glassy phase that formed at the outer part of the oxide layer after exposure at $1350^{\circ} \mathrm{C}$ for $1000 \mathrm{~h}$. In contrast, mullite grains were equiaxed, with no glassy phase in the as-hot-pressed composites, as mentioned elsewhere. ${ }^{18}$ The prismatic morphology, together with the grain-boundary glassy phase, suggest that these prismatic mullite grains were secondary and formed via the solution-reprecipitation mechanism. ${ }^{45,46}$ As the oxidation of $\mathrm{SiC}$ whiskers proceeded, the average composition changed in the direction of increasing $\mathrm{SiO}_{2}$. Because impurities, which were incorporated into $\mathrm{SiO}_{2}$ and/or mullite, caused the change in chemical potential of these phases, interdiffusion between $\mathrm{SiO}_{2}$ and mullite could occur, whereby aluminosilicate compounds were formed. Furthermore, impurities lowered the eutectic point of the mullite and $\mathrm{SiO}_{2}$. After a liquid phase had formed at the interfaces, the solubility of the solid phase increased, thus expediting matter transport, followed by rapid grain growth. Consequently, prismatic secondary mullite grains formed only near the severely oxidized surface.

\section{(3) Transformation Routes in the $\mathrm{MgO}-\mathrm{Al}_{2} \mathrm{O}_{3}-\mathrm{SiO}_{2}$ Phase Diagram}

Significant compositional changes, which occurred in the oxidized regions of the composites, had an effect on the long-term oxidation of the composites. The transformation routes followed during the long-term oxidation of SiC-whisker-reinforced mullite/ $\mathrm{MgO}$-partially stabilized $\mathrm{ZrO}_{2}$ composites can be described as follows. The original matrix was composed of mullite $\left(3 \mathrm{Al}_{2} \mathrm{O}_{3} \cdot 2 \mathrm{SiO}_{2}\right)$, spinel $\left(\mathrm{MgAl}_{2} \mathrm{O}_{4}\right)$, and a small amount of sapphirine. The composition is designated point $\mathrm{A}$ in the $\mathrm{Al}_{2} \mathrm{O}_{3}-$ $\mathrm{SiO}_{2}-\mathrm{MgO}$ ternary phase diagram, as shown in Fig. 9, and is located very close to the alkemade line connecting mullite and spinel. On the surface of the exposed sample, the amount of $\mathrm{SiO}_{2}$ increased because of the oxidation of $\mathrm{SiC}$ whiskers; $\mathrm{MgO}$ was enriched by long-range diffusion or exsolution from mullite grains. Thus, the composition moved from points A to B, located inside the spinel-sapphirine-mullite triangle.

This movement from point A to point B indicates that spinel and sapphirine are two predominant oxidation products in the early stage, as observed earlier. Then, with the approximately fixed ratio of $\mathrm{Al}_{2} \mathrm{O}_{3}$ and $\mathrm{MgO}$, further increase in $\mathrm{SiO}_{2}$ made the composition move along the line BS. Depending on the extent of oxidation, two

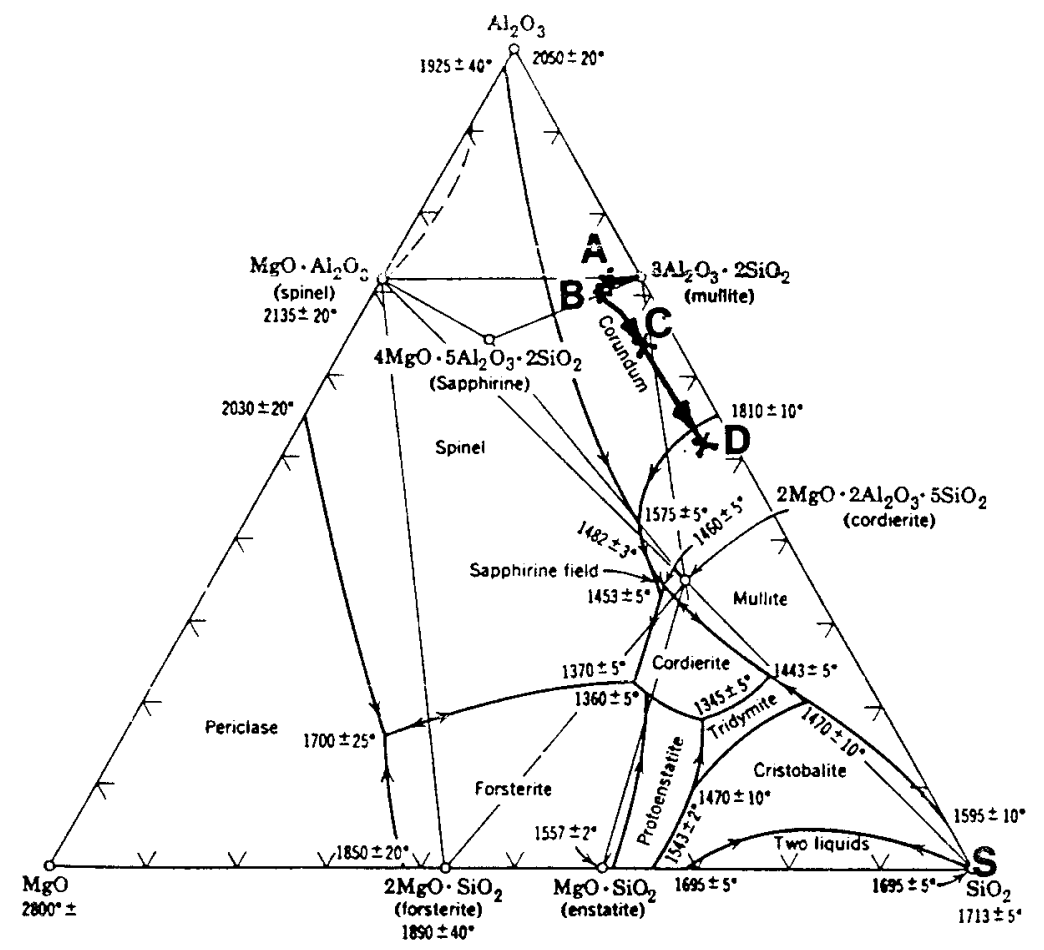

Fig. 9. $\mathrm{Al}_{2} \mathrm{O}_{3}-\mathrm{SiO}_{2}-\mathrm{MgO}$ ternary phase diagram, showing compositional changes in the exposed composite. 
different situations could occur: If the new composition was point $\mathrm{C}$ inside the mullite-cordierite-sapphirine triangle, then sapphirine and cordierite would coexist in the oxide layer, as in the sample exposed at $1250^{\circ} \mathrm{C}$ for $500 \mathrm{~h}$. With further oxidation of the $\mathrm{SiC}$ whiskers, the composition would shift to point $\mathrm{D}$ inside the mullite-cordierite-silica triangle. Thus, cordierite would be the only $\mathrm{MgO}-\mathrm{Al}_{2} \mathrm{O}_{3}-\mathrm{SiO}_{2}$ compound in the severely oxidized surface, as in the sample exposed at $1350^{\circ} \mathrm{C}$ for $1000 \mathrm{~h}$.

\section{Conclusions}

(1) In the exposed samples, amorphous $\mathrm{SiO}_{2}$ formed because of the oxidation of $\mathrm{SiC}$ whiskers. After extended exposure, the amorphous $\mathrm{SiO}_{2}$ devitrified into cristobalite at $T \geq 1200^{\circ} \mathrm{C}$ or quartz at lower temperatures.

(2) The matrix was stable at $1000^{\circ} \mathrm{C}$. At $T \geq 1200^{\circ} \mathrm{C}$, the reaction between $\mathrm{ZrO}_{2}$ and $\mathrm{SiO}_{2}$ resulted in zircon, and prismatic secondary mullite grains seemed to form via the solutionreprecipitation mechanism in the severely oxidized samples.

(3) During exposure at $T \geq 1200^{\circ} \mathrm{C}$, the reaction between $\mathrm{MgO}$ and $\mathrm{Al}_{2} \mathrm{O}_{3}$ produced an aluminum-magnesium spinel. Further addition of $\mathrm{SiO}_{2}$ to the spinel caused the formation of sapphirine and/or cordierite.

(4) The significant compositional changes, which occurred in the oxidized regions of the composites, clearly affected the long-term oxidation of the composites.

\section{References}

${ }^{1}$ G. C. Wei and P. F. Becher, "Development of SiC-Whisker-Reinforced Ceramics," Am. Ceram. Soc. Bull., 64 [2] 298-304 (1985).

${ }^{2}$ N. Claussen and G. Petzow, "Whisker-Reinforced Zirconia-Toughened Ceramics"; pp. 649-62 in Tailoring Multiphase and Composite Ceramics. Edited by R. E. Tressler, G. L. Messing, C. G. Pantano, and R. E. Newnham. Plenum Press, New York, 1986.

${ }^{3}$ R. Ruh, K. S. Mazdiyasni, and M. G. Mendiratta, "Mechanical and Microstructural Characterization of Mullite and Mullite-SiC-Whisker and $\mathrm{ZrO}_{2}$-Toughened Mullite-SiC-Whisker Composites," J. Am. Ceram. Soc., 71 [6] 503-12 (1988).

${ }^{4}$ P. F. Becher, C. H. Hsueh, P. Angelini, and T. N. Tiegs, "Toughening Behavior in Whisker-Reinforced Ceramic-Matrix Composites," J. Am. Ceram. Soc., 71 [12] 1050-61 (1988)

${ }^{5}$ M. I. Osendi, B. A. Bender, and D. Lewis III, "Microstructure and Mechanical Properties of Mullite-Silicon Carbide Composites," J. Am. Ceram. Soc., 72 [2] 1049-54 (1989)

${ }^{6}$ J. R. Porter and A. H. Chokshi, "Creep Performance of Silicon Carbide-WhiskerReinforced Alumina"; pp. 919-28 in Ceramic Microstructure '86: Role of Interface. Edited by J. A. Pask and A. G. Evans. Plenum Press, New York, 1987.

${ }^{7}$ P. F. Becher and T. N. Tiegs, "Temperature Dependence of Strengthening by Whisker Reinforcement: SiC-Whisker-Reinforced Alumina in Air," Adv. Ceram. Mater., 3 [2] 148-53 (1988).

${ }^{8}$ M. P. Borom, M. K. Brun, and L. E. Szala, "Kinetics of Oxidation of Carbide and Silicide Dispersed Phases in Oxide Matrices," Adv. Ceram. Mater., 3 [5] 491-97 (1988).

${ }^{9}$ K. L. Luthra and H. D. Park, "Oxidation of Silicon Carbide-Reinforced OxideMatrix Composites at $1375^{\circ}$ to $1575^{\circ}$ C," J. Am. Ceram. Soc., 73 [4] 1014-23 (1990).

${ }^{10}$ M. I. Osendi, "Oxidation Behavior of Mullite-SiC Composites," J. Mater. Sci., 25, 3561-65 (1990)

${ }^{11}$ H. Y. Liu, K. L. Weisskopf, M. J. Hoffmann, and G. Petzow, "Oxidation Behavior of SiC-Whisker-Reinforced Mullite $\left(-\mathrm{ZrO}_{2}\right)$ Composites," J. Eur. Ceram. Soc., 5, 122-33 (1989).

${ }^{12}$ C. Baudin and J. S. Moya, "Oxidation of Mullite-Zirconia-Alumina-Silicon Carbide Composites," J. Am. Ceram. Soc., 73 [5] 1417-20 (1990).

${ }^{13}$ M. Backhaus-Ricoult, "Oxidation Behavior of SiC-Whisker-Reinforced Alumina-Zirconia Composites," J. Am. Ceram. Soc., 74 [8] 1793-802 (1991).

${ }^{14}$ C. C. Lin, A. Zangvil, and R. Ruh, "Modes of Oxidation in SiC-Reinforced Mullite/ZrO $\mathrm{Zr}_{2}$-Based Composites: Oxidation versus Depth Behavior," Acta Mater., 47 [6] 1977-86 (1999).

${ }^{15}$ C. Y. Tsai, C. C. Lin, A. Zangvil, and A. K. Li, "Effect of Zirconia Content on the Oxidation Behavior of Silicon Carbide/Zirconia/Mullite Composites," J. Am. Ceram. Soc., 81 [9] 2413-20 (1998).
${ }^{16}$ C. Y. Tsai and C. C. Lin, "Dependence of Oxidation Modes on Zirconia Content in Silicon Carbide/Zirconia/Mullite Composites," J. Am. Ceram. Soc., 81 [12] 3150-56 (1998)

${ }^{17}$ C. C. Lin, A. Zangvil, and R. Ruh, "Microscopic Mechanisms of Oxidation in SiC-Whisker-Reinforced Mullite/ $\mathrm{ZrO}_{2}$-Matrix Composites," J. Am. Ceram. Soc., 82 [10] 2833-40 (1999).

${ }^{18}$ A. Zangvil, C. C. Lin, and R. Ruh, "Microstructural Studies in Alkoxide-Derived Mullite/Zirconia/Silicon Carbide-Whisker Composites," J. Am. Ceram. Soc., 75 [5] 1254-63 (1992).

${ }^{19}$ G. Cliff and G. W. Lorimer, "The Quantitative Analysis of Thin Specimens," $J$. Microsc. (Oxford), 103 [2] 203-207 (1975).

${ }^{20} \mathrm{G}$. van Tendeloo, J. van Landuyt, and S. Amelinckx, "The $\alpha \rightarrow \beta$ Phase Transition in Quartz and $\mathrm{AlPO}_{4}$, as Studied by Electron Microscopy and Diffraction," Phys. Status Solidi A, 33 [2] 723-35 (1976).

${ }^{21}$ D. R. Peacor, "High-Temperature Single-Crystal Study of the Cristobalite Inversion," Z. Kristallogr., 138, 274-98 (1973).

${ }^{22}$ R. L. Withers, J. G. Thompson, and T. R. Welberry, "The Structure and Microstructure of $\alpha$-Cristobalite and Its Relationship to Cristobalite," Phys. Chem. Miner., 16 [6] 517-23 (1989).

${ }^{23}$ G. L. Hua, T. R. Welberry, R. L. Withers, and J. G. Thompson, "An Electron Diffraction and Lattice-Dynamical Study of the Diffuse Scattering in $\beta$-Cristobalite, $\mathrm{SiO}_{2}$," J. Appl. Crystallogr., 21 [5] 458-65 (1988).

${ }^{24}$ C. C. Wang and P. J. Zanzucchi, "Dielectric and Optical Properties of Stoichiometric Magnesium Aluminate Spinel Single Crystals," J. Electrochem. Soc., 118 [4] 586-91 (1971)

${ }^{25}$ M. Ishii, J. Hiraishi, and T. Yamanaka, "Structure and Lattice Vibrations of Mg-Al Spinel Solid Solution," Phys. Chem. Miner., 8 [2] 64-68 (1982).

${ }^{26}$ H. Suematsu, T. Suzuki, T. Iseki, and T. Mori, "Decoration of Dislocations by the Precipitation of Alumina in $\mathrm{MgO}-2.9 \mathrm{Al}_{2} \mathrm{O}_{3}$ Spinel," J. Am. Ceram. Soc., 72 [8] 1449-52 (1989)

${ }^{27}$ R. M. Smart and F. P. Glasser, "The Subsolidus Phase Equilibria and Melting Temperatures of $\mathrm{MgO}-\mathrm{Al}_{2} \mathrm{O}_{3}-\mathrm{SiO}_{2}$ Composites," Ceram. Int., 7 [3] 90-97 (1981).

${ }^{28}$ F. C. Bishop and R. C. Newton, "The Composition of Low-Pressure Synthetic Sapphirine," J. Geol., 83 [4] 511-17 (1975).

${ }^{29}$ A. G. Christy and A. Putnis, "Planar and Line Defects in the Sapphirine Polytypes," Phys. Chem. Miner., 15 [6] 548-58 (1988).

${ }^{30}$ J. Barbier and B. G. Hyde, "Structure of Sapphirine: Its Relation to the Spinel, Clinopyroxene, and $\beta$-Gallia Structures," Acta Crystallogr., Sect. B: Struct. Sci., B44 [4] 373-77 (1988)

${ }^{31}$ G. V. Gibbs, "The Polymorphism of Cordierite: I. The Crystal Structure of Low Cordierite," Am. Mineral., 51 [7] 1068-87 (1966).

${ }^{32}$ E. P. Meagher and G. V. Gibbs, "The Polymorphism of Cordierite: II. The Crystal Structure of Indialite," Can. Mineral., 15 [1] 43-49 (1977).

${ }^{33}$ A. Miyashiro, "Cordierite-Indialite Relation," Am. J. Sci., 255 [1] 4362 (1957).

${ }^{34}$ A. Putnis, "The Distortion Index in Anhydrous Mg-Cordierite," Contrib. Mineral. Petrol., 74 [2] 135-41 (1980).

${ }^{35}$ A. Putnis and D. L. Bish, "The Mechanism and Kinetics of Al,Si Ordering in Mg-Cordierite," Am. Mineral., 68 [1] 60-65 (1983).

${ }^{36}$ H. L. M. van Roermund and R. J. Konert, "Deformation and Recrystallization Mechanisms in Naturally Deformed Cordierite," Phys. Chem. Miner., 17 [1] 52-61 (1990).

${ }^{37}$ W. Zdaniewski, "DTA and X-ray Analysis Study of Nucleation and Crystallization of $\mathrm{MgO}-\mathrm{Al}_{2} \mathrm{O}_{3}-\mathrm{SiO}_{2}$ Glasses Containing $\mathrm{ZrO}_{2}, \mathrm{TiO}_{2}$, and $\mathrm{CeO}_{2}$," J. Am. Ceram. Soc., 58 [5-6] 163-69 (1975).

${ }^{38}$ G. F. Neilson, "Nucleation and Crystallization in $\mathrm{ZrO}_{2}$-Nucleated Glass-Ceramic System"; pp. 78-82 in Advances in Nucleation and Crystallization in Glasses. Edited by L. L. Hench and S. W. Freiman. American Ceramic Society, Columbus, OH, 1971.

${ }^{39}$ T. I. Barry, J. M. Cox, and R. Morrell, "Cordierite Glass-Ceramics: Effect of $\mathrm{TiO}_{2}$ and $\mathrm{ZrO}_{2}$ Content on Phase Sequence during Heat Treatment," J. Mater. Sci., 13 [3] 594-610 (1978).

${ }^{40}$ A. H. Heuer and G. L. Nord Jr., "Polymorphic Phase Transitions in Minerals", pp. 271-303 in Applications of Electron Microscopy in Mineralogy. Edited by H. R. Wenk. Springer-Verlag, Berlin, Germany, 1976.

${ }^{41}$ J. Copreaux, M. Gandais, and S. C. Duion, "Growth and Ordering Processes in Synthetic Hydrothermal Anorthite," Phys. Chem. Miner., 16 [6] 545-50 (1989).

${ }^{42}$ G. van Tendeloo, S. Ghose, and S. Amelinckx, "A Dynamic Model for the P $\overline{1} \rightarrow$ I1 Phase Transition in Anorthite, $\mathrm{CaAl}_{2} \mathrm{Si}_{2} \mathrm{O}_{8}$ : I. Evidence from Electron Microscopy," Phys. Chem. Miner., 16 [4] 311-19 (1989).

${ }^{43}$ K. M. Trappen and R. A. Eppler, "Reaction of Zirconia with Silica at the Stoichiometry of Zircon," J. Am. Ceram. Soc., 72 [6] 882-85 (1989).

${ }^{44}$ R. A. Eppler, "Mechanism of Formation of Zircon Stains," J. Am. Ceram. Soc., 53 [8] 457-62 (1970).

${ }^{45} \mathrm{P}$. Drew and M. H. Lewis, "The Microstructures of Silicon Nitride Ceramics during Hot-Pressing Transformations," J. Mater. Sci., 9 [21] 261-69 (1974).

${ }^{46}$ M. H. Lewis, B. D. Powell, P. Drew, R. J. Lumby, B. North, and A. J. Taylor, "The Formation of Single-Phase Si-Al-O-N Ceramics," J. Mater. Sci., 12 [1] 61-74 (1977). 